\title{
Severity of leaf diseases in maize inbred lines with different kernel hardness in two sowing seasons
}

\section{Severidade de doenças foliares em linhagens de milho com diferentes texturas de grãos em duas épocas de semeadura}

\author{
Cecília Aparecida Spada ${ }^{1}$; Marcos Ventura Faria ${ }^{2 *}$; Marcelo Cruz Mendes ${ }^{2}$; \\ Welton Luiz Zaluski ${ }^{3}$; Emanuel Gava ${ }^{1}$; Carlos Augusto da Silva \\ Diego Fernando De Marck ${ }^{1}$; Cacilda Márcia Duarte Rios Faria ${ }^{2}$
}

\begin{abstract}
Resistance of maize inbred lines to major leaf diseases should be characterized for the development of new hybrids in breeding programs. Thus, this study aimed to assess the severity of leaf diseases in maize inbredlines with different kernel hardnessand two sowingseasons. We assessed four inbred lines and one check hybrid with dent kernels and four inbred lines and a check hybrid with flint kernels. Treatments were conducted in two sowing seasons, one in October, and another in December 2013. The symptoms of gray leaf spot (Cercospora zeae-maydis), northern leaf blight (Exserohilum turcicum), and white leaf spot (a complex of Phaeosphaeria maydis and Pantoea ananatis) were assessed every 10 days from flowering. The area under the disease progress curve was also calculated. Severity level of the diseases was higher in inbred lines when compared to the check hybrds (AG8041 PRO and P30R50YH), regardless of kernel hardness. Dent-kernel inbred lines showed a higher severity of northern leaf blight symptoms when compared to flint-kernelones. It is worth mentioning that disease severity increased as sowing was delayed.
\end{abstract}

Keywords: Cercospora zeae-maydis. Exserohilum turcicum. Pantoea ananatis. Phaeosphaeria maydis. Zea mays.

\section{Resumo}

A caracterização de linhagens de milho quanto à resistência às principais doenças é fundamental para o desenvolvimento de novos híbridos em programas de melhoramento. Assim, o objetivo deste trabalho foi avaliar a severidade de doenças foliares em linhagens de milho com diferentes texturas de grãos em duas épocas de semeadura. Foram avaliadas quatro linhagens e um híbrido testemunha com grãos dentados e quatro linhagens e um híbrido testemunha com grãos duros. Os tratamentos foram conduzidos em duas épocas de semeadura, em outubro e em dezembro de 2013. A partir do florescimento, a cada 10 dias, foram avaliadas as doenças foliares cercosporiose (Cercospora zeae-maydis), helmintosporiose (Exserohilum turcicum) e mancha branca (complexo Phaeosphaeria maydis/Pantoea ananatis). Foi calculada a área abaixo da curva do progresso das doenças (AACPD). A severidade das doenças

\footnotetext{
${ }^{1}$ Discentes de Mestrado, Programa de Pós-Graduação em Agronomia/Produção Vegetal, Universidade Estadual do Centro Oeste, UNICENTRO, Guarapuava, PR, Brasil. E-mail: spadacecilia@hotmail.com; emanuel_gava2@hotmail.com; diegofernandodemarck@hotmail.com

2 Profs. Drs., Departamento de Agronomia, UNICENTRO, Guarapuava, PR, Brasil. E-mail: mfaria@unicentro.br; mcmendes@ unicentro.br; criosfaria@hotmail.com

${ }^{3}$ Discente de Doutorado, Programa de Pós-graduação em Agronomia/Produção Vegetal, UNICENTRO, Guarapuava, PR, Brasil. E-mail: luizzaluski@hotmail.com

${ }^{4}$ Pesquisador Melhorista, Geneze Sementes, Londrina, PR, Brasil. E-mail: guilherme@geneze.com.br

*Author for correspondence
} 
foi maior nas linhagens, comparativamente aos híbridos testemunhas AG8041 PRO e P30R50YH, independentemente da textura dos grãos. As linhagens de textura dentada apresentaram maior severidade de sintomas da helmintosporiose, quando comparada às linhagens de grãos duros. Houve aumento da severidade das doenças avaliadas com o atraso da semeadura.

Palavras-chave: Cercospora zeae-maydis. Exserohilumturcicum. Pantoea ananatis. Phaeosphaeria maydis. Zea mays.

\section{Introduction}

Second cycle inbred lines are commonly obtained from commercial hybrids in maize breeding. In this process, the knowledge on the characteristics and performance of inbred lines is essential for selecting the best ones, aiming at directing the crosses to be assessed based on their combining ability (OLIBONI et al., 2013).

When assessing maize genotypes with forage purpose, kernel endosperm hardness should be considered, as this trait exerts influence on the final silage quality (ROSSI et al., 2016), as does leaf health (QUEIROZ et al., 2009; WEATHERLY et al., 2016).

Maize crops occupy a vast geographical area and are under diverse edaphoclimatic conditions, so being exposed to several pathogens causing leaf fungal diseases, which impair its efficiency (BRITO et al., 2013). It occurs because these pathogenic organisms reduce photosynthetic area and, consequently, synthesis and translocation of assimilates (GOMES et al., 2011). In many cases, the damages are considered as indirect because the reduction in leaf area predisposes the plants to stem and ear rot pathogens (PROCHNO et al., 2016).

Genetic resistance is effective to control maize leaf diseases (PROCHNO et al., 2016); therefore, genetic breeding programs seek to develop inbred lines and hybrids with higher resistance levels (SILVEIRA et al., 2006). Several studies in the literature point to a genetic variability for resistance to leaf diseases in some maize cultivars (NIHEI; FERREIRA, 2012; VIEIRA et al., 2012), but a few of them approach the genetic resistance of inbred lines (SILVEIRA et al., 2006; VIVEK et al., 2010; SAITO et al., 2016).
Even with high genetic value, the inbred lines should be evaluated for hybrid combinations and respective performances. This is because the susceptibility to the main foliar diseases impairs either the performance as genitors in seed production fields or the genetic resistance to be manifested in hybrids (NIHEI; FERREIRA, 2012).

Thus, this study aimed to assess the severity of symptoms of leaf diseases in experimental maize inbred lines with forage aptitude and different kernel hardness in two sowing seasons.

\section{Material and Methods}

Two experiments were carried out in an experimental field belonging to the Department of Agronomy, Universidade Estadual do CentroOeste - UNICENTRO (Midwest State University), CEDETEG campus, in Guarapuava, Paraná State, Brazil. It is located at the geographical coordinates $25^{\circ} 21^{\prime} \mathrm{S}$ and $51^{\circ} 30^{\prime} \mathrm{W}$ and $1,100 \mathrm{~m}$ of altitude. The soil is classified as a typical dystroferric brown latosol (Oxisol) with a very clayey texture (EMBRAPA, 2006). According to Köppen's classification (PEREIRA et al., 2002), the climate is classified as $C f b$, which stands for a subtropical climate with no defined dry season, mean annual rainfall of $1,800 \mathrm{~mm}$, and mean air temperature from October to March of $19^{\circ} \mathrm{C}$.

Ten maize genotypes were assessed in the experiments: four experimental dent-kernel inbred lines and four flint-kernel inbred lines, both of populations from commercial hybrids. The other two genotypes were commercial hybrids and used as check treatments (Table 1). 
Table 1. Characteristics of maize genotypes assessed in two sowing seasons in the 2013/2014 crop season in Guarapuava - PR, Brazil.

\begin{tabular}{ccccc}
\hline Genitor hybrid & Genetic basis/Genotype & $\begin{array}{c}\text { Kernel } \\
\text { Hardness }\end{array}$ & Program* & Identification \\
\hline AG 8080 & line $\mathrm{S}_{6}$ D7-H3.01 & Dent & UEM & M01D \\
CD 303 & line $\mathrm{S}_{6}$ D 88-H4.01 & Dent & UEM & M02D \\
P30B39 & line $\mathrm{S}_{4}$ D102-157.3 & Dent & UNICENTRO & G01D \\
P30B39 & line $\mathrm{S}_{4}$ D102-1.2 & Dent & UNICENTRO & G02D \\
AG8041 PRO & Single hybrid & Dent & Agroceres/Monsanto & AG8041 PRO \\
DKB 747 & line $\mathrm{S}_{6}$ F47-H17.5 & Flint & UEM & M01F \\
P30F33 & line $\mathrm{S}_{6}$ F70-H26.1 & Flint & UEM & M02F \\
AS1560 & line $\mathrm{S}_{4}$ F202-203.1 & Flint & UNICENTRO & G01F \\
P30B39 & line $\mathrm{S}_{4}$ F102-226.1 & Flint & UNICENTRO & G02F \\
P30R50 YH & Single hybrid & Flint & Du Pont/Pioneer & P30R50 YH \\
\hline
\end{tabular}

*UEM = Universidade Estadual de Maringá (State University of Maringá), UNICENTRO = Universidade Estadual do CentroOeste (Midwest State University).

The experiments were carried out on October 10 and December 20, 2013, respectively, in a no-tillage system, in an area desiccated with glyphosate and grown with black oat (Avena strigosa Schreb.) as a predecessor crop.

The experimental design was a randomized blocks with three replications. Each plot consisted of three rows of four meters in length, spaced $0.70 \mathrm{~m}$ apart, and a population of 64,000 plants ha- ${ }^{-1}$.

Seeds were treated with imidacloprid + thiodicarb, following the manufacturer's recommendations. Sowing was made manually in rows previously furrowed and fertilized. In the base fertilization, $300 \mathrm{~kg} \mathrm{ha}^{-1}$ of the NPK formulation 8-28-16 was used. The first topdressing fertilization was performed at the V3-V4 stage and the second topdressing fertilization was performed at the V6-V7 stage, using $200 \mathrm{~kg} \mathrm{ha}^{-1}$ of urea in each application. In this study, no application of foliar fungicide was conducted.

Weed control was performed with atrazine + simazine at a dose of $1 \mathrm{~L} \mathrm{ha}^{-1}$. Insects were controlled with imidacloprid + beta-cyfluthrin at a dose of 0.75 $\mathrm{L} \mathrm{ha}^{-1}$, chlorantraniliprole at a dose of $0.15 \mathrm{~L} \mathrm{ha}^{-1}$, and lufenuron at the dose of $0.15 \mathrm{~L} \mathrm{ha}^{-1}$.
The data of air temperature, rainfall, and solar radiation during the experimental period were obtained from the meteorological station located at the CEDETEG campus (Table 1).

Every ten days from flowering, four evaluators were in charge of five assessments of leaf-disease symptoms naturally occurring in plants of each plot. Scores from 1 to 9 were assigned using the diagrammatic scale proposed by Agroceres (1996).

The assessed leaf diseases were gray leaf spot (Cercospora zeae-maydis), northern leaf blight (Exserohilum turcicum), and white leaf spot (a complex of Phaeosphaeria maydis and Pantoea ananatis). Severity means were used to calculate the area under the disease progress curve (AUDPC), according to Shaner and Finney (1977).

The data were submitted to the individual analysis of variance considering each experiment. The analyses of normality were conducted by the Shapiro-Wilk test and the homogeneity of residual variances was performed by Bartlett's test (RAMALHO et al., 2000). Based on the assumptions, the joint analyses of variance were conducted and the means were grouped by the ScottKnott test at $5 \%$ probability by using the statistical software Genes (CRUZ, 2013). 
Different contrasts in the endosperm hardness were estimated between the means of groups of inbred lines and check hybrids, whose significance was verified by the Bonferroni t-test by using the statistical software Sisvar at 5\% probability (FERREIRA, 2011).

\section{Results and Discussion}

A significant effect of genotypes was observed for the areas under the foliar diseases progress curves, i.e. northern leaf blight(AUNLBPC), white leaf spot (AUWLSPC), and gray leaf spot (AUGLSPC) (Table 2), demonstrating the existence of variability among genotypes of different kernel hardness for the severity progression of these diseases. The significant effect of thesowing season on AUNLBPC, AUWLSPC, and AUGLSPC (Table 2) confirms such an effect onthe intensity of leaf disease symptoms in maize crops (GONÇALVES et al., 2012).

Table 2. Summary of joint variance analysis for severity of leaf diseases expressed by areas under foliar diseases progress curves of northern leaf blight (AUNLBPC), white leaf spot (AUWLSPC), and gray leaf spot (AUGLSPC) for 10 maize genotypes with contrasting kernel hardness and assessed in two sowing seasons in the 2013/2014 crop season, in Guarapuava - PR, Brazil.

\begin{tabular}{|c|c|c|c|c|c|c|c|}
\hline SV & DF & AUNLBPC & & AUWLSPC & & AUGLSPC & \\
\hline Block/Season & 4 & 5691.46 & & 5026.10 & & 39414.57 & $* *$ \\
\hline Season (S) & 1 & 52618.74 & $* *$ & 2089572.94 & & 8302675.44 & $* *$ \\
\hline Genotype (G) & 9 & 36362.22 & $* *$ & 108261.91 & $* *$ & 147593.91 & $* *$ \\
\hline Dent (D) & 4 & 32775.48 & & 927953.43 & $* *$ & 155430,76 & $* *$ \\
\hline Flint (F) & 4 & 43985.29 & $* *$ & 134886.84 & $* *$ & 176135,01 & $* *$ \\
\hline $\mathrm{D} \times \mathrm{F}$ & 1 & 20216.9 & $* *$ & 6925.39 & & 2082,11 & \\
\hline $\mathrm{G} \times \mathrm{S}$ & 9 & 14216.17 & $* *$ & 108254.59 & $* *$ & 94936.93 & $* *$ \\
\hline $\mathrm{D} \times \mathrm{S}$ & 4 & 7583.46 & $*$ & 107042.00 & $* *$ & 100077,61 & $* *$ \\
\hline $\mathrm{F} \times \mathrm{S}$ & 4 & 23570.94 & $* *$ & 134798.05 & $* *$ & 112572,52 & $* *$ \\
\hline$($ D vs. $F) \times S$ & 1 & 3327.93 & & 6931.11 & & 3831,85 & \\
\hline Error & 36 & 2452.40 & & 3232.95 & & 6214.51 & \\
\hline CV\% & & 40.10 & & 30.45 & & 17.83 & \\
\hline Mean & & 123.51 & & 186.73 & & 442.22 & \\
\hline
\end{tabular}

$* *$ and $*$ are significant at $1 \%$ and $5 \%$ probability, respectively, by the $\mathrm{F}$ test.

The degrees of freedom of genotypes were sliced into two groups, i.e. dent and flint genotypes. No significant difference was observed for AUNLBPC among dent genotypes (Table 2). For the other diseases, significant differences were observed for severity of symptoms among genotypes within both groups, demonstrating the existence of variability in the resistance level.

The genotype-seasoninteraction was significant for all assessed leaf diseases (Table 2), which demonstrates the differentiated genotype behavior regarding the severity at different sowing seasons. Engelsing et al. (2011) assessed the combining ability of five maize lines and their respective hybrids and found a significant effect of the interaction hybrids $\times$ locals for the severity of gray leaf spot. Significant interactions of genotypes $\times$ environments regarding the resistance to white leaf spot were also observed by Vivek et al. (2010), and Nihei and Ferreira (2012).

The significant effect of the interactions dent genotypes $\times$ seasons, flint genotypes $\times$ seasons, 
and the contrast dent vs. flint $\times$ seasons (Table 2) indicates the differentiated behavior of each group or contrast between them when submitted to different growing conditions. The interactions dent genotypes $\times$ seasons and flint genotypes $\times$ seasons were significant for all diseases, indicating a variation in the response of dent and flint genotypes to leaf-disease fungal agents in face of environmental variations determined by different growing seasons (Table 2).

Variations in air temperature, relative air humidity, and solar radiation over the experimental period (Figure 1) possibly contributed to the significant interactions of genotypes with growing seasons. Two groups were formed in season 1 and three in season 2 for AUNLBPC (Figure 2). The inbred lineM02D was classified in the group with higher means of AUNLBPC in both seasons, showing a higher susceptibility. The flint-kernel inbred line M01F was classified in the group with lower AUNLBPC resistance, i.e. it presented a higher resistance to northern leaf blight in both seasons, with no difference from the check hybrids AG8041PRO and P30R50YH (Figure 2). The mean values of severity of northern leaf blight symptoms in the last assessment ranged from $0.5 \%$ (M01F) to 23.3\% (M01D) in season 1 and from $2.5 \%(\mathrm{P} 30 \mathrm{R} 50 \mathrm{YH})$ to $32.2 \%(\mathrm{G} 01 \mathrm{~F})$ in season 2. Favorable conditions for the development of northern leaf blight are relative air humidity above $60 \%$ and nighttime temperatures around $14{ }^{\circ} \mathrm{C}$ (GONÇALVES et al., 2012). In southern Brazil, northern leaf blight is considered as one of the main leaf spots in maize crops (VIEIRA et al., 2012); hitherto, resistant genotypes constitute anessential strategy to reduce the losses caused by such disease.

Figure 1. Air-temperature, rainfall, and solar radiation during the experiment period, covering the two assessed seasons, in a ten-day period. Data gathered from the IAPAR Meteorological Station, located at the CEDETEG campus of UNICENTRO, in Guarapuava - PR, Brazil.

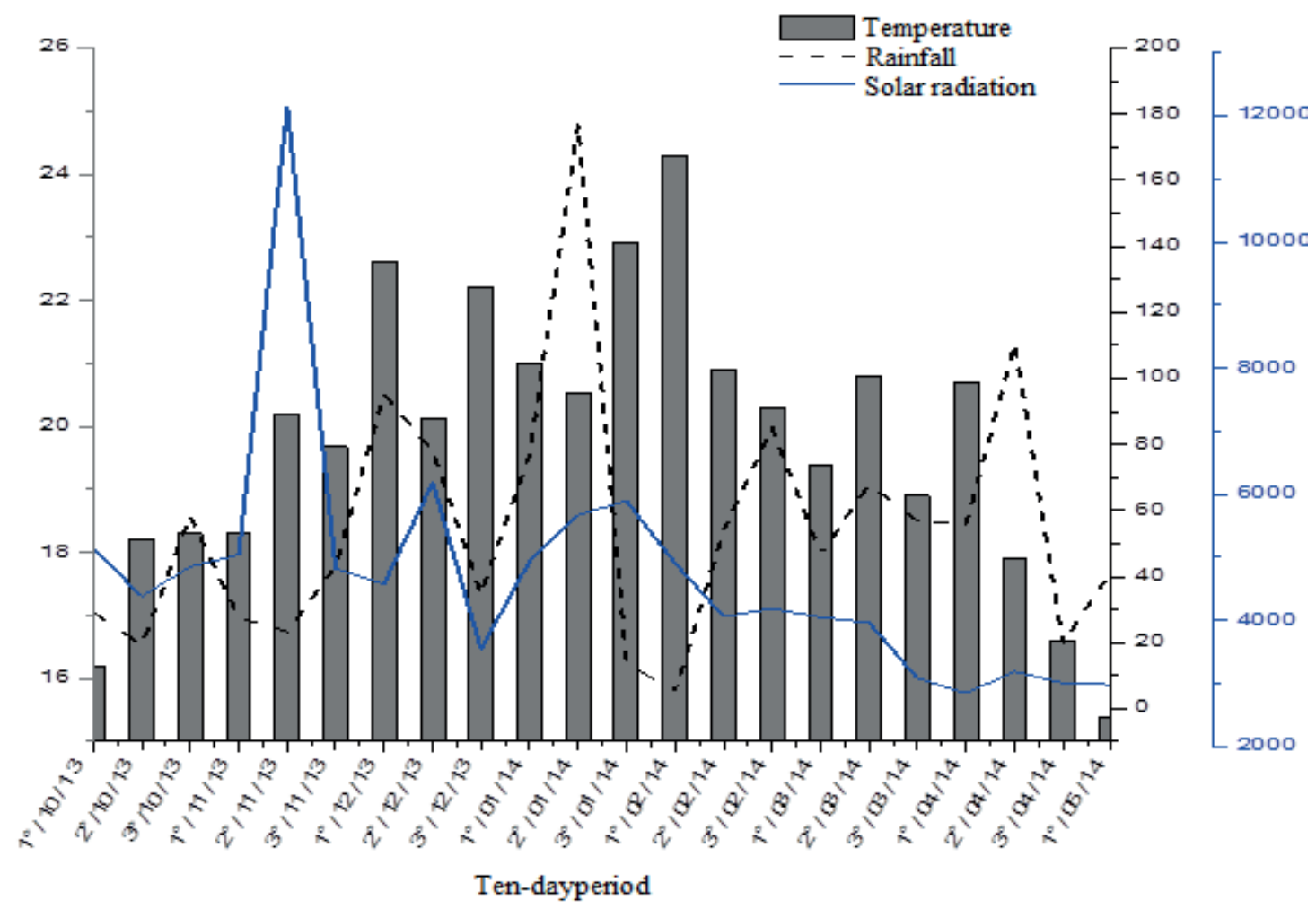


Figure 2. Area under northern leaf blight progress curve (AUNLBPC) for 10 maize genotypes with contrasting kernel hardness and assessed in two sowing seasons, in the 2013/2014 crop season, in Guarapuava-PR, Brazil. Lowercase letters group genotypes within each season by the Scott-Knott test $(\mathrm{P}<0.05)$ and uppercase letters compare means of seasons for each genotype by the F-test $(\mathrm{P}<0.05)$.

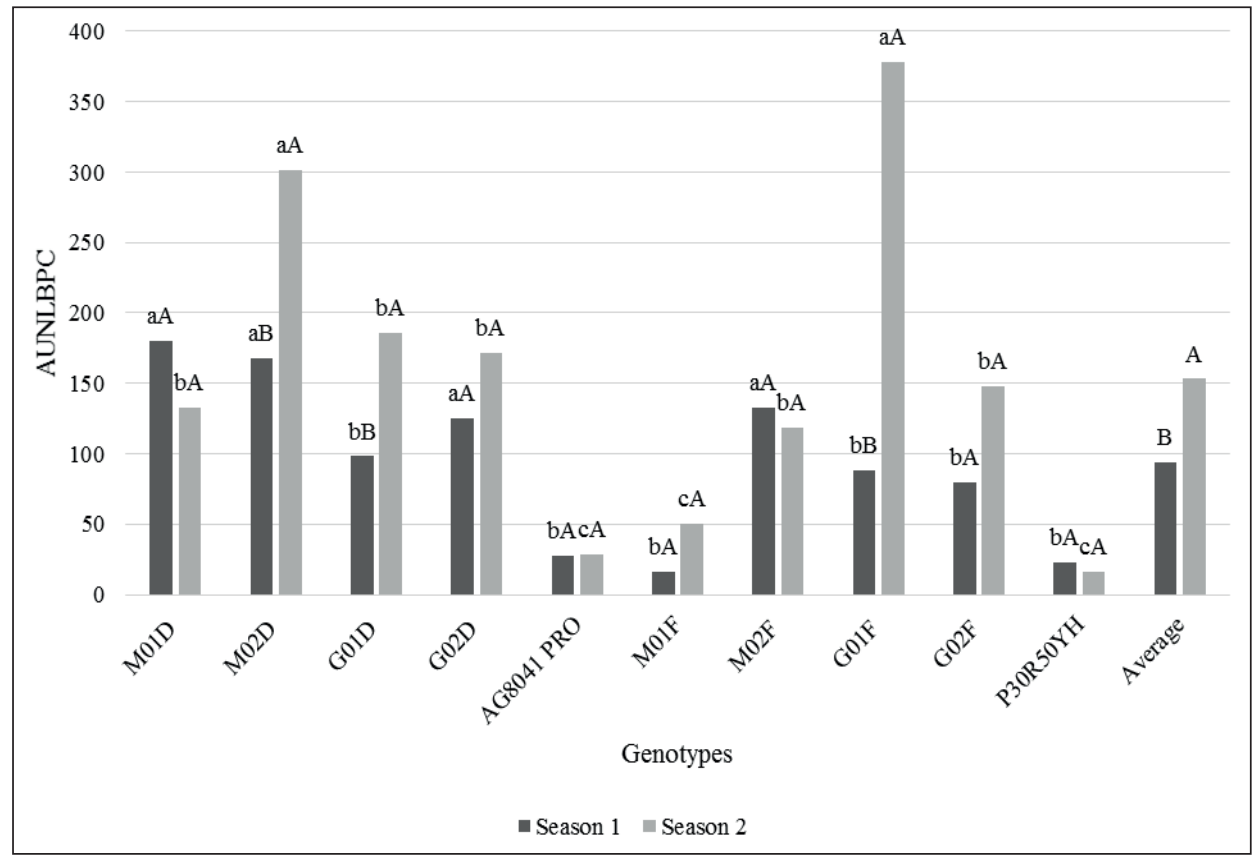

The overall mean of white leaf spot severity progress (AUWLSPC) was significantly higher in season 2, as there were no signs in season 1 (Figure 3). This shows the effect of environmental conditions of late planting, usually exposing the crop to high rainfalls, and providing adequate conditions for the development of this disease (COSTA et al., 2011; GONÇALVES et al., 2012).

In season 2, the lines G01D and M02F presented the highest values of AUWLSPC, significantly differing from the other genotypes. On the other hand, the dent inbred line M01F presented the lowest mean of AUWLSPC, demonstrating a higher resistance to white leaf spot (Figure 3). In the last assessment of season 2, the severity of white leaf spot varied from $0.4 \%(\mathrm{M} 01 \mathrm{~F})$ to $68.8 \%$ (G01D).

Leaf diseases lead to a negative impact on the development and production of maize related to the destruction of photosynthetic tissues, which occurs due to an increase in the number of lesions. This may lead to leaf necrosis and premature death, limiting solar radiation interception and translocation of photosynthates for further kernel development and green-forage tissue maintenance to a silage of high quality (QUEIROZ et al., 2009; WEATHERLY et al., 2016), when it is needed.

Genotypes were highly affected by gray leaf spot in season 2, with an overall AUGLSPCmeanof 814.21. In the last assessment of season 2, the severity of symptoms ranged from $38.8 \%$ (P30R50YH) to 75.5\% (M02F), considering the used scale (AGROCERES, 1996). On the other hand, in season 1, the severity was less significant, with no difference among genotypes for AUGLSPC (Figure 4). In the last assessment, it ranged from $0.4 \%$ (M01F) to $25.5 \%$ (G01D), showing the influence of climatic conditions occurring in season 2, with diurnal air temperatures above $22^{\circ} \mathrm{C}$ and night time air temperatures lower than $18^{\circ} \mathrm{C}$ (Figure 1), which favored the development of the fungus Cercospora zeae-maydis. Solar radiation was higher in season 1 , with a value of $70,725 \mathrm{cal} \mathrm{cm}^{2}$ 
day $^{-1}$, when compared to season 2 , which presenteda value of 55,339 $\mathrm{calcm}^{2}$ day $^{-1}$ (Figure 1). The low light radiation conditions after flowering, in season
2 (Figure 1), also favored a higher severity of gray leaf spot (Figure 5) since cloudy days are favorable to the development of this disease (PINTO et al., 2006).

Figure 3. Area under white leaf spot progress curve (AUWLSPC) for 10 maize genotypes with contrasting kernel hardness and assessed in two sowing seasons, in the 2013/2014 crop season, in Guarapuava - PR, Brazil. Lowercase letters group genotypes within each season by the Scott-Knott test $(\mathrm{P}<0.05)$ and uppercase letters compare means of seasons for each genotype by the F-test $(\mathrm{P}<0.05)$.

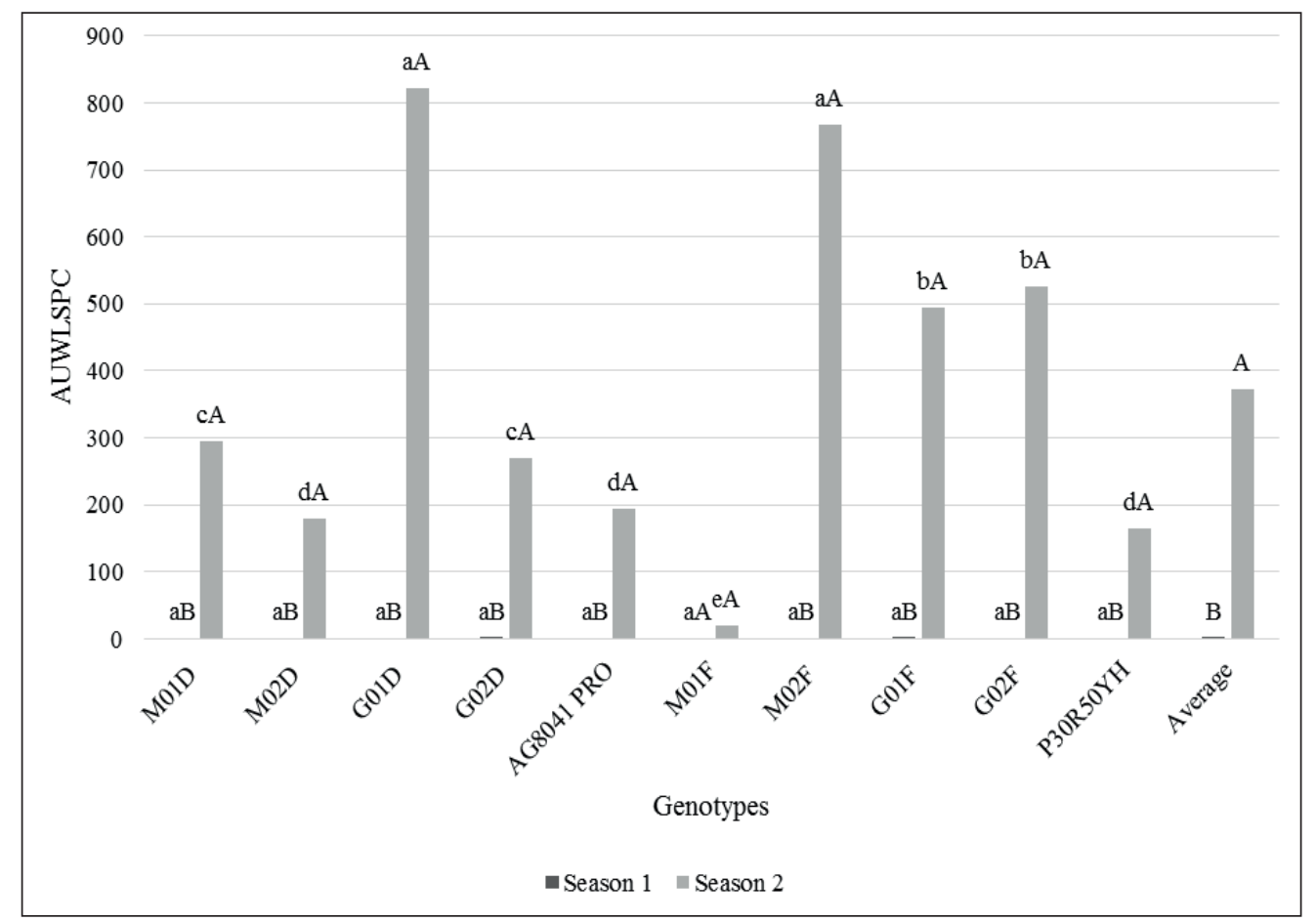

The inbred line G01F presented a high value of AUGLSPC in season 2 (Figure 4). This inbred line was obtained from the hybrid AS1560, which presented a high severity of gray leaf spot symptoms in experiments assessed by Gralak et al. (2015) in Guarapuava and Candói, Paraná State, Brazil.

Different studies show the existence of genetic variability in white leaf spot (NIHEI; FERNANDES, 2012), northern leaf blight, and gray leaf spot (VIEIRA et al., 2012) in lines and hybrids of maize.
When contrasting DH vs. FL, estimates showed the major susceptibility of dent hybrid AG8041PRO to northern leaf blight when compared to the mean of flintkernellines, but only in season 2 . The group of flintkernellines showed a higher susceptibility to white leaf spotwhen considering the meanof both seasons, and to gray leaf spot when considering the season 2 (Table 3). 
Figure 4. Area under gray leaf spot progress curve (AUGLSPC) for 10 maize genotypes with contrasting kernel hardness and assessed in two sowing seasons, in the 2013/2014 crop season, in Guarapuava - PR, Brazil. Lowercase letters group genotypes within each season by the Scott-Knott test $(\mathrm{P}<0.05)$ and uppercase letters compare means of seasons for each genotype by the $\mathrm{F}$-test $(\mathrm{P}<0.05)$.

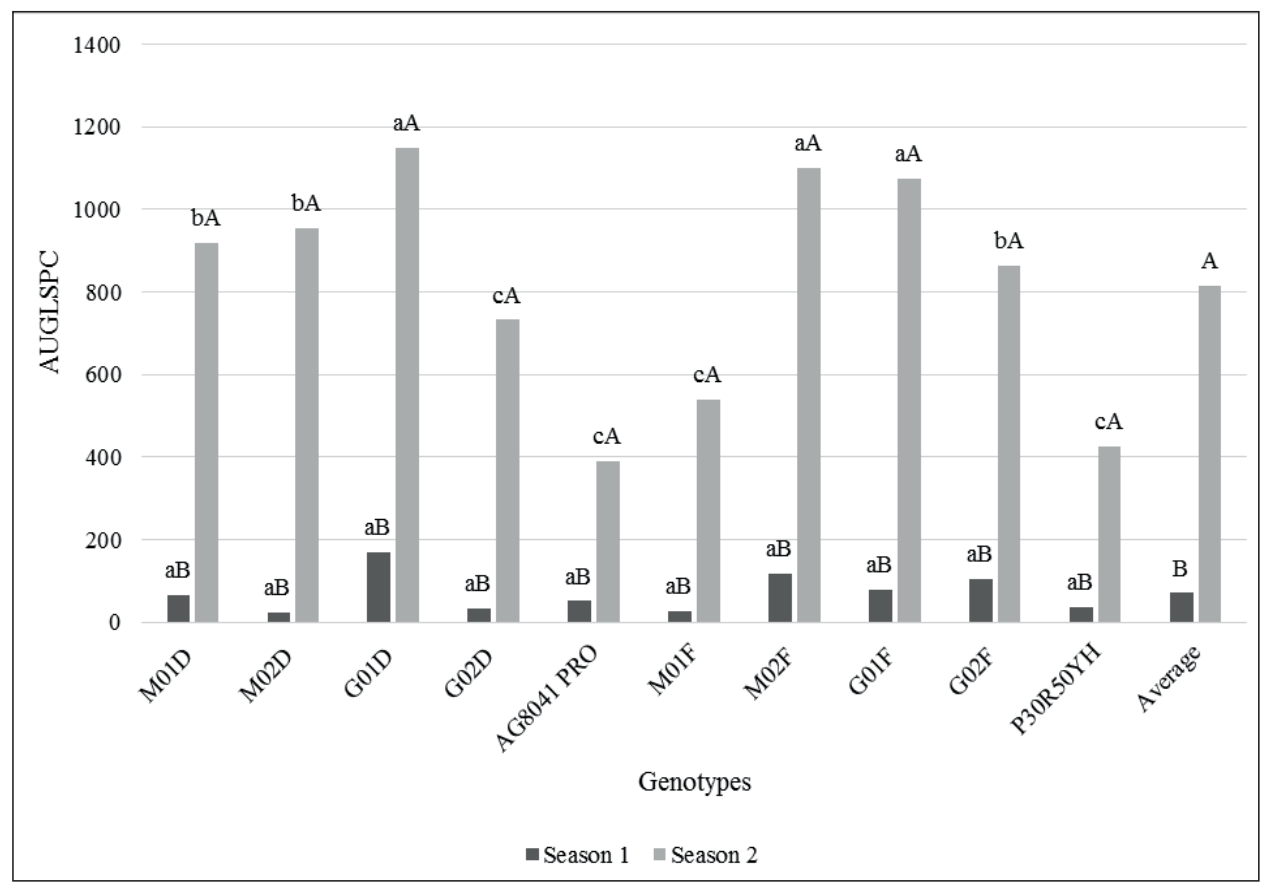

Figure 5. Areas under leaf diseases progress curves of northern leaf blight (AUNLBPC), white leaf spot (AUWLSPC), and gray leaf spot (AUGLSPC) for 10 maize genotypes with different kernel hardness and assessed in two sowing seasons, in the 2013/2014 crop season, in Guarapuava - PR, Brazil.

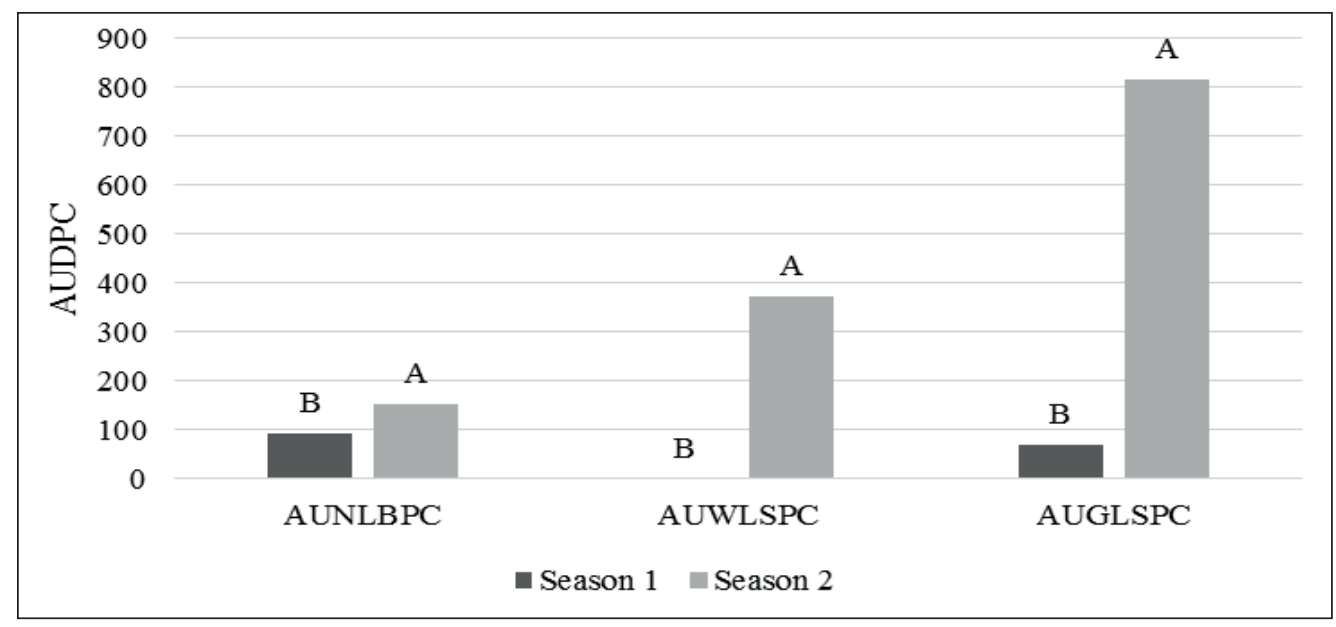

The estimates of the contrast FH vs. DL, which compares the behavior of the flint kernel hybrid P30R50YH with the average performance of dent kernel lines, showed the higher susceptibility of lines to northern leaf blight in both seasons, white leaf spot in the joint mean, and gray leaf spot only in season 2 (Table 3 ).
The contrast FH vs. FL followed the same pattern as the other comparisons, demonstrating a lower resistance of flint kernel lines when compared to the hybrid P30R50YH. In season 1, there was no significant difference among these genotypes for gray leaf spot (Table 3). 
Table 3. Estimates and significance of contrasts between means of dent hybrids vs. flint lines (DH vs. FL), flint hybrid vs. dent lines (FH vs. DL), flint hybrid vs. flint lines (FH vs. FL), dent hybrid vs. flint hybrid (DH vs. FH), dent hybrid vs. dent lines (DH vs. DL), and dent lines vs. flint lines (DL vs. FL) for areas under northern leaf blight (AUNLBPC), white leaf spot (AUWLSPC), and gray leaf spot (AUGLSPC) progress curves for 10 genotypes with different kernel hardness assessed in two sowing seasons in the 2013/2014 crop season in Guarapuava - PR, Brazil.

\begin{tabular}{|c|c|c|c|c|c|c|c|c|c|}
\hline \multirow[b]{2}{*}{ Variable } & \multicolumn{3}{|c|}{ DH vs. FL } & \multicolumn{3}{|c|}{ FH vs. DL } & \multicolumn{3}{|c|}{ FH vs. FL } \\
\hline & Season 1 & Season 2 & Joint & Season 1 & Season 2 & Joint & Season 1 & Season 2 & Joint \\
\hline AUNLBPC & 52.10 & $145.29 * *$ & & $-119.68 * *$ & $-181.61 * *$ & & -56.19 & $-157.35 * *$ & \\
\hline AUWLSPC & & & $-129.13 * *$ & & & $-113.35 * *$ & & & $-143.91 * *$ \\
\hline \multirow[t]{2}{*}{ AUGLSPC } & -30.72 & $-504.14 * *$ & & -36.69 & $-512.01 * *$ & & -45.69 & $-468.36 * *$ & \\
\hline & \multicolumn{3}{|c|}{ DH vs. FH } & \multicolumn{3}{|c|}{ DH vs. DL } & \multicolumn{3}{|c|}{ DL vs. FL } \\
\hline Variable & Season 1 & Season 2 & Joint & Season 1 & Season 2 & Joint & Season 1 & Season 2 & Joint \\
\hline$\overline{\text { AUNLBPC }}$ & 4.08 & 12.05 & & $-115.59 * *$ & $-169.55 * *$ & & $63.48 * *$ & 24.25 & \\
\hline AUWLSPC & & & 14.77 & & & $-98.58 * *$ & & & -30.55 \\
\hline AUGLSPC & 14.87 & -35.78 & & -21.72 & $-547.79 * *$ & & -8.99 & 43.65 & \\
\hline
\end{tabular}

** and * are significant at $1 \%$ and $5 \%$ probability, respectively, by the Bonferroni t-test.

Estimates of DH vs. FH contrast, which compares the check hybrids, had noeffect onthe evolution symptom severity for leaf diseases in both seasons (Table 2). This outcome shows the lack of influence from differences between kernel hardness on the resistance levels of these hybrids.

The estimates of the contrast DH vs. DL, which compares the behavior of dent hybrids (AG8041 PRO) with the average performance of dent kernel lines, showed a higher susceptibility of lines when compared to the hybrid for northern leaf blight in both seasons and gray leaf spot in season 2. In addition, dent kernel lines were more susceptible to white leaf spot when compared to the hybrid AG8041 PRO when considering the mean of both seasons (Table 2).

The contrast DL vs. FL analyzes the average behavior of groups of dent and flint kernel lines. In season 1, dent kernel lines were more susceptible to northern leaf blight when compared to the mean of flint kernel lines (Table 2).

\section{Conclusions}

Leaf diseases were more severe in maize inbred lines when compared to hybrids AG8041 PRO and P30R50YH (checks), regardless of kernel hardness.
Dent-kernel inbred lines presented a higher severity of symptoms for northern leaf blight if compared to flint-kernel ones.

The assessed leaf diseases were more severe in the second sowing season, which is a late season.

\section{Acknowledgements}

The authors thank CNPq, FINEP, and Fundação Araucária for the financial support and CAPES for granting a master's scholarship to the first author.

\section{References}

AGROCERES. Guia Agroceres de sanidade. São Paulo: Sementes Agroceres, 1996. 72 p.

BRITO, A. H.; VON PINHO, R. G.; PEREIRA, J. L. A. R.; BALESTRE, M. Controle químico da Cercosporiose, Mancha-Branca e dos Grãos Ardidos em milho. Revista Ceres, Viçosa, MG, v. 60, n. 5, p. 629-635, 2013.

COSTA, R. V.; COTA, L. V.; SILVA, D. D.; LANZA, F. E. Recomendações para o controle químico da mancha branca do milho. Sete Lagoas: Embrapa Milho e Sorgo, 2011. 6 p. (Embrapa Milho e Sorgo, Circular técnica, 167).

CRUZ, C. D. Genes: a software package for analysis in experimental statistics and quantitative genetics. Acta ScientiarumAgronomy, Maringá, v. 35, n. 3, p. 271-276, 2013. 
EMPRESA BRASILEIRA DE PESQUISA AGROPECUÁRIA - EMBRAPA. Centro Nacional de Pesquisa de Solos. Sistema brasileiro de classificação de solos. 2. ed. Rio de Janeiro: Embrapa Solos, 2006. 306 p.

ENGELSING, M. J.; ROZZETTO, D. S.; COIMBRA, J. L. M.; ZANIN, C. G.; GUIDOLIN A. F. Capacidade de combinação em milho para resistência a Cercospora zeae-maydis. Revista Ciência Agronômica, Fortaleza, v. 42, n. 1, p. 232-241, 2011.

FERREIRA, D. F. Sisvar: a computer statistical analysis system. Ciência e Agrotecnologia, Lavras, v. 35, n. 6, p. 1039-1042, 2011.

GOMES, E. C. S.; LEITE, R. P.; SILVA, F. J. A.; CAVALCANTI, L. S.; NASCIMENTO, L. C.; SILVA, S. M. Manejo do míldio e ferrugem em videira com indutores de resistência: produtividade e qualidade póscolheita. Tropical PlantPathology, Viçosa, MG, v. 36, n. 5, p. 332-335, 2011.

GONÇALVES, M. E. M. P.; GONÇALVES JÚNIOR, D.; SILVA, A. G.; CAMPOS, H. D.; SIMON, G. A.; SANTOS, C. J. L.; SOUSA, M. A. Viabilidade do controle químico de doenças foliares em híbridos de milho no plantio de safrinha. Nucleus, Ituverava, v. 9, n. 1, p. 49-61, 2012.

GRALAK, E.; FARIA, M. V.; ROSSI, E. S.; POSSATTO JUNIOR, O.; GABRIEL, A.; MENDES, M. C.; SCAPIM, C. A.; NEUMANN, M. Capacidade combinatória de híbridos de milho para produção de grãos e severidade de doenças foliares em dialelo circulante. Revista Brasileira de Milho e Sorgo, Sete Lagoas, v. 14, n. 1, p. 116-129, 2015.

NIHEI, T. H.; FERREIRA, J. M. Análise dialélica de linhagens de milho com ênfase na resistência a doenças foliares. Pesquisa Agropecuária Brasileira, Brasília, v. 47, n. 3, p. 369-377, 2012.

OLIBONI, R.; FARIA, M. V.; NEUMANN, M.; RESENDE, J. T. V.; BATTISTELLI, G. M.; TEGONI, R. G.; OLIBONI, D. F. Análise dialélica na avaliação do potencial de híbridos de milho para a geração de populações-base para obtenção de linhagens. Semina: Ciências Agrárias, Londrina, v. 34, n. 1, p. 7-18, 2013.

PEREIRA, A. R.; ANGELOCCI, L. R.; SENTELHAS, P. C. Agrometeorologia: Fundamentos e aplicações práticas. Guaíba: Agropecuária, 2002. 478 p.

PINTO, N. F. J. A.; SANTOS, M. A.; WRUCK, D. S. M. Principais doenças da cultura do milho. Informe Agropecuário, Belo Horizonte, v. 27, n. 233, p. 7-12, 2006.

PROCHNO, H. C.; COELHO, C. J.; ROMANEK, C.; SILVA, D. F. G.; TASIOR, D.; OLIVEIRA, E. A.T.;
GARDINGO,J.R.;MATIELLO,R.R.Geneticresistance of maize inbred lines to anthracnose leaf blight. Crop Breeding and Applied Biotechnology, Viçosa, MG, v. 16, n. 1, p. 55-61, 2016.

QUEIROZ, O. C. M.; ADESOGAN, A. T.; KIM, S. C. Effect of rust infestation on silage quality. In: INTERNATIONAL SILAGE CONFERENCE, 15., 2009, Madison. Proceeding... Madison: USDA, 2009. p. 303-304.

RAMALHO, M. A. P.; FERREIRA, D. F.; OLIVEIRA, A. C. Experimentação em genética e melhoramento de plantas. Lavras: UFLA, 2000. 326p.

ROSSI, E. S.; FARIA, M. V.; MENDES, M. C.; NEUMANN, M.; GABRIEL, A.; DEL CONTE, M. V. Bromatological characteristics and ruminal digestibility of grain corn hybrids with different vitreousness in silage maturity. Acta Scientiarum Agronomy, Maringá, v. 38, n. 3, p. 337-344, 2016.

SAITO, B. C.; SILVA, L. Q.; ANDRADE, J. A. C.; GOODMAN, M. M. Resistance of corn inbred lines to foliar diseases in two planting dates. International Journal of Environmental \& Agriculture Research, Ijoear, v. 2, n. 10, p. 21-28, 2016.

SHANER G.; FINNEY, R. F. The effects of nitrogen fertilization on the expression of show-mildwing in knox wheat. Phytopathology, Saint Paul, v. 67, p. 1051-1055, 1977.

SILVEIRA, F. T.; JUNQUEIRA, B. G.; SILVA, P. C.; MORO, J. R. Comportamento de linhagens elites de milho para resistência aos enfezamentos. Revista Brasileira de Milho e Sorgo, Sete Lagoas, v.5, n. 3, p. 431-442, 2006.

VIEIRA, R. A.; SCAPIM, C. A.; MOTERLE, L. M.; TESSMANN, D. J.; AMARAL JUNIOR, A. T.; GONÇALVES, L. S. A.; AMARAL JÚNIOR, A. T.; GONÇALVES, L. S. A. The breeding possibilities and genetic parameters of maize resistance to foliar diseases. Euphytica, Wageningen, v. 185, n. 3, p.325-336, 2012.

VIVEK, B. S.; ODONGO, O.; NJUGUNA, J.; IMANYWOHA, J.; BIGIRWA, G.; PIXLEY, K. Diallel analysis of grain yield and resistance to seven diseases of 12 African maize (Zea mays L.) inbred lines. Euphytica, Wageningen, v. 172, n. 3, p. 329-340, 2010.

WEATHERLY, M.; KALEBICH, C.; ROBINSON, K.; FELlOWS, G. M.; CARDOSO, P. C. Chemical composition and fermentation profile of corn silage ensiled for zero, thirty, ninety, or one hundred fifty days from corn treated with a foliar fungicide at different growing stages. Journal of Animal Science, Champaign, v. 94, n. 5, p. 698-698, 2016. 